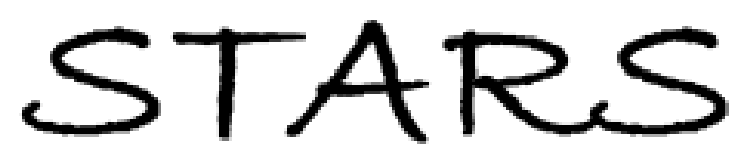

University of Central Florida

STARS

Faculty Scholarship and Creative Works

2017

\title{
Size, Functional Heterogeneity, and Teamwork Quality Predict Team Creativity and Innovation
}

Robert L. Dipboye

University of Central Florida, rdipboye@knights.ucf.edu

Part of the Human Resources Management Commons, Industrial and Organizational Psychology Commons, Organizational Behavior and Theory Commons, and the Social Psychology Commons

Find similar works at: https://stars.library.ucf.edu/ucfscholar

University of Central Florida Libraries http://library.ucf.edu

This Paper is brought to you for free and open access by STARS. It has been accepted for inclusion in Faculty Scholarship and Creative Works by an authorized administrator of STARS. For more information, please contact STARS@ucf.edu.

\section{Original Citation}

Dipboye, R. L. (2017). Size, functional heterogeneity and teamwork quality predict team creativity and innovation. Unpublished manuscript.

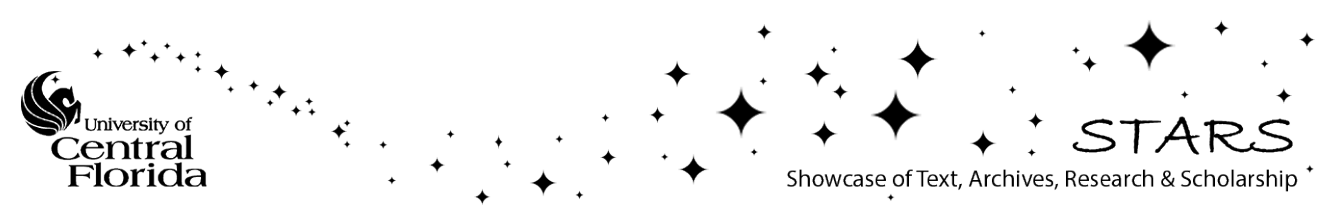


Size, Functional Heterogeneity, and Teamwork Quality

Predict Team Creativity and Innovation

\author{
Robert L. Dipboye \\ University of Central Florida
}

Correspondence;

Robert L. Dipboye

938 Golfside Drive

Winter Park, Fl 32792

dipboye@rice.edu 


\begin{abstract}
Team size, heterogeneity, and an aggregate measure of teamwork quality predicted the effectiveness of organizational problem solving teams in generating ideas and obtaining the acceptance of management for these ideas. The results of regression analyses revealed that large teams generated more total and implemented ideas than smaller teams. In addition to more total and implemented ideas, teams with higher functional heterogeneity and teamwork quality generated more total and implemented ideas per member. Team size also moderated the effects of self-reported teamwork quality such that larger teams showed a stronger positive relation of teamwork quality with total and implemented ideas than smaller teams. Management evaluations of the teams were unrelated to size, functional heterogeneity, and teamwork quality. The findings support the treatment of team size as an important predictor of effectiveness rather than relegating it to the status of a mere control variable. Also, the results support previous observations that subjective judgments of team effectiveness are not equivalent to objective measures and that researchers should use multiple criteria of team success. Finally, rather than relying on concurrent, cross-sectional designs, research is needed that uses predictive models to assess how well team characteristics forecast effectiveness.

Work teams, group heterogeneity, group size, team innovation, teamwork
\end{abstract}




\section{Size, Functional Heterogeneity, and Teamwork Quality Predict Team Creativity and Innovation}

To gain competitive advantage in a complex and interdependent world, organizations are using teams of employees rather than relying solely on the efforts of individuals (Alexander \& Van Knippenberg, 2014). A frequent objective of these efforts is team innovation, defined as "the intentional introduction and application within a team, of ideas, processes, products or procedures new to the team, designed to significantly benefit the individual, the team, the organization, or wider society” (West \& Wallace, 1991, p. 303). Team innovation is found not only in the typical traditional work group, but also in a variety of less permanent entities such as quality improvement, cross-functional, re-engineering, and advice and consultation groups. At the core of team innovation in organizational contexts are the generation, selection, and implementation of creative ideas. Although researchers have found support for using teams, skeptics point to significant gaps in what is known about the factors associated with team effectiveness and question whether the empirical evidence is sufficient to justify the current enthusiasm (e.g., Allen \& Hecht, 2004; Locke, Tirnauer, Roberson, Goldman, Latham \& Weldon, 2001; Naquin \& Tynana, 2003). Clearly, more research is needed with actual teams working in organizational contexts. Pursuant to closing these gaps in knowledge, the present study explored three potential leverage points for understanding and improving team innovation the quality of teamwork, functional heterogeneity, and team size. 


\section{Teamwork Quality}

Research and theory suggest that the members of teams that are effective in generating innovative solutions to problems interact with one another and with those outside the teams in ways that lead to the open and constructive exchange of information, positive relationships among members, the motivation to work for the success of the team, and coordination of their efforts. In the present study, I subsume a variety of processes under the general rubric of teamwork quality. Among the processes that theory and research identify as components of high quality teamwork are the following:

1. An absence of negative team processes. The superior productivity achieved when ideas of members are pooled in nominal groups is often the consequence of process losses that plague face-to-face interaction (Mullen, Johnson, \& Salas, 1991; Shepperd, 1993; Steiner, 1972). These process losses include lack of coordination, relational conflict, social loafing, domination by a few members, lack of planning, conformity, rush to judgment, and other dysfunctional behavior that prevent teams from reaching their potential.

2. Member participation and voice. In teams with high quality teamwork, members participate in the team's work and perceive that they have an opportunity to express their opinions (West \& Anderson, 1996). Full participation facilitates the use of member resources, builds commitment to decisions, and engenders a sense of justice.

3. Organization. A team with high quality teamwork is well organized in that it uses an agenda, meets in a comfortable space free of distraction, begins and ends on time, and uses a facilitator (Cohen, Rogelberg, Allen, \& Luong, 2011). Additionally, meetings are planned and conducted in a manner that makes the best use of the time available. 
4. Motivation. Another component of high quality teamwork is a high level of member motivation to achieve the task goals and other objectives of the group. Shepperd (1993) proposes that members are motivated to work effectively in a team when “.....(a) there is sufficient incentive to contribute, (b) individuals perceive their own efforts as consequential in achieving a desired outcome, and (c) the costs of contributing are not excessive, exceeding the benefits derived from contributing” (p. 78). The research has shown that expectation of rewards is especially important as a determinant of team functioning (Rousseau \& Aubé, 2014; Shaw, Duffy \& Stark, 2001). Also important are members’ expectations that their ideas will be accepted (Baer, 2012) and that they will succeed across a variety of tasks (Gully, Incalcaterra, Joshi, \& Beaubien, 2002; Shea \& Guzzo, 1987; Stajkovic, Lee \& Nyberg, 2009),

5. Openness to dissent and constructive, task-oriented conflict. Where there is high quality teamwork, members engage in constructive conflict over task related issues and avoid relational conflict, arguing solely for the sake of arguing, and conflicts aimed at furthering selfinterests (De Dreu, 2002; Schmidt \& Kochan, 1972; West \& Andersen, 1996). Moreover, members not only tolerate but also welcome minority opinions.

6. Boundary management. Teams that are tasked with generating innovative ideas are typically embedded within an organizational context and must manage the boundaries between the group and management, other groups, coworkers, and customers (Ancona \& Caldwell, 1992; Somech \& Khalaili, 2014). A particularly important outcome of effective boundary management that research has shown to be positively related to team effectiveness is supervisory support (Randel, Jaussi, \& Wu, 2011; Škerlavaj, Černe \& Dysvikn, 2014; Somech \& Drach-Zahavy, 2013; West \& Anderson, 1996). 
Summary. Teamwork quality is an aggregate construct consisting of a variety of factors commonly associated with team effectiveness. These include lack of negative processes, high levels of meeting organization, member motivation, participation and voice, boundary management, and openness to task conflict. A large amount of research and theory supports the importance of teamwork quality as a predictor of creativity and innovation. This leads to the first hypothesis tested in the present study:

Hypothesis 1: Teams whose members report higher levels of quality teamwork are more effective in generating innovative ideas and gaining managerial acceptance than teams reporting lower teamwork quality.

\section{Functional Heterogeneity}

When forming organizational teams, an important question is the extent to which members are chosen who represent diverse areas of expertise, disciplinary backgrounds, and task functions. Functional heterogeneity is potentially a double-edged sword and can harm as well as benefit team performance (Kong-Hee, 2014). Notwithstanding the potential for conflict and other dysfunctional consequences, meta-analyses show that functional heterogeneity is positively related to team creativity and innovation (Bell, Villado, Lukasik, Belau \& Briggs, 2011; Somech \& Crach-Zahavy, 2013; Hülsheger, Anderson and Salgado, 2009; van Dijk, van Engen \& van Knippenberg, 2012). There are several potential advantages of functional heterogeneity. The most frequently cited are the greater cognitive resources and diverse viewpoints that allow the team to think out of the box (Drach-Zahavy \& Somech, 2001; Hülsheger et al., 2009; Webber \& Donahue, 2001). A second, less frequently mentioned advantage is that members in a heterogeneous team have more communication links with persons outside the group, and these links serve as conduits for ideas (Perry-Smith \& Shalley, 2014). Functional heterogeneity also 
can improve performance by facilitating substantive task disagreements and debate (Simons, Pelled \& Smith, 1999) and by encouraging questioning, reanalysis, and reflection (Somech, 2006).

Based on previous research and theory, the following hypothesis was set forth for the relation of functional heterogeneity to team innovation.

Hypothesis 2: Teams that are more heterogeneous in the functional areas represented by team members are more effective in generating innovative ideas and gaining managerial acceptance of these ideas than more functionally homogeneous teams.

\section{Team Size}

In addition to functional heterogeneity, the other consideration in forming a team is how many members to assign to the team. The most frequent advice is form small teams, perhaps no more than five to seven members (e.g., Useem, 2006). Large groups purportedly encourage free riding and social loafing (Liden, Wayne, Jaworski, \& Bennett, 2004), more conformity to the majority (Bond, 2005), a lack of coordination (Hare, 1981; Thomas \& Fink, 1963), inequalities in member participation (Bales, Strodtbeck, Mills, \& Roseborough, 1951; Bray, Kerr \& Atkin, 1978), errors in the forecasting of the time and effort required to perform the team task (Staats, Milkman and Fox, 2012), less social support within the group (Mueller, 2012), and information overload (Baruah \& Paulus, 2011; Kolfschoten \& Brazier, 2013).

Contrary to the frequent warning to keep teams small, the results of two comprehensive meta-analyses indicate that there is a small, positive relation of size and team innovation (Hülsheger, et al, 2009; Thatcher \& Patel, 2011). Also, the laboratory research on brainstorming is consistent in showing a positive relation of team size and performance (Mullen, Johnson \& Salas, 1991; Valacich, Wheeler, Mennecke \& Wachter, 1995). There are several reasons that a 
large number of members is often advantageous in generating innovative ideas. Teams with more members have a larger pool of knowledge, skills, and abilities to use in performing its tasks (Steiner, 1972, p. 87-88). Larger teams have more slack resources that allow members to keep working even when unexpected events prevent some from attending meetings or getting involved (Moreland, Levine \& Wingert, 1996). Large teams provide members with a greater sense of security and potentially reduce anxieties that interfere with the performance of tasks (Cunningham \& Chelladurai, 2004). Larger teams also activate semantic networks that aid recall (Brown \& Paulus, 2002) and stimulate greater effort on tasks as a consequence of social comparisons (Dugosh \& Paulus, 2005) and social facilitation (Geen, 1989).

Summary. The research on group size has produced a mix bag of results, but when teams are involved in generating innovative ideas, the theory and research supports the contention that larger sizes are associated with higher performance. This leads to the third hypothesis:

Hypothesis 3: Larger teams are more effective in generating innovative ideas and gaining managerial acceptance of these ideas than smaller teams.

\section{The Moderating Influence of Team Size}

Team size is usually considered a covariate and is seldom examined in field research as a potential moderator of factors identified as correlates of team effectiveness. The absence of such tests in source studies prevents any meaningful exploration of size as a moderator in metaanalyses (see LePine, Piccolo, Jackson, Mathieu \& Saul, 2008, p. 294). The largest amount of support for the moderating effects of size comes from the laboratory research on brainstorming. This work has shown consistently that, in the generation of ideas, nominal groups perform better than interacting groups (Mullen, Johnson \& Salas, 1991) and electronic brainstorming groups perform better than face-to-face groups (Dennis \& Williams, 2005). Size moderates these effects 
in so far as stronger effects are found in larger groups. Similarly, Valacich, Wheeler, Mennecke and Wachter (1995) found in a laboratory experiment with electronic brainstorming that numerical group size interacted with informational heterogeneity. There were larger performance gains from increased heterogeneity as the number of group members increased.

Despite the laboratory evidence, whether size moderates the effects of team size and functional heterogeneity remains an open question because so few field studies include tests for the moderating effects of size. Cohen, et al (2011) provide one of the few exceptions in a study in which they found a stronger positive impact of a facilitator in larger groups. There are theoretical justifications for predicting that size is a moderator. One could extrapolate to team innovation from the social impact theory proposition that larger group size amplifies the effects of a variety of social processes (Latane', 1981). Another argument is that the paucity of unique ideas in a small team places a ceiling on the extent to which teamwork quality and functional heterogeneity can boost innovation and that innovative potential is only realized with the large pool of ideas associated with a larger team (see Valacich et al, 1995). It is possible that the benefits of functional heterogeneity and size are only achieved when both are relatively large. In a homogeneous team, where members bring similar ideas to the task, adding more members yields smaller marginal gains in the number of unique ideas. Increasing size in a homogeneous team could even lead to groupthink and other negative processes that stifle creativity. By contrast, in a heterogeneous team where members bring different ideas to the task, increasing the number of members generates a larger marginal gain in the production of unique ideas.

An implication of a dual - task interference paradigm (see Heninger, Dennis, \& Hilmer, 2006; Dennis \& Williams, 2005) is that efforts to enhance teamwork quality in a small team potentially divert resources from the core task of generating ideas. When there are few members, 
less effort is required to ensure high quality teamwork. Monitoring and managing internal processes might even distract from member attention to the task and damage effectiveness. By contrast, the risks of process losses are greater in a large team and the benefits of attending to internal processes outweigh the costs.

Summary. There are surprisingly few field tests of the moderating effects of size but the laboratory evidence and some theory suggest that the effects of size and heterogeneity depend on team size. As stated in the following hypothesis, team size was expected to moderate the relation of teamwork quality and functional heterogeneity with team innovation.

Hypothesis 4: The positive relation of team effectiveness and teamwork quality increases in strength as team size increases.

Hypothesis 5: The positive relation of team effectiveness and functional heterogeneity increases in strength as team size increases.

\section{Method}

\section{The Organization and Group Program}

The organization was a utility company with over 10,000 employees and expenditures of about 4 billion dollars. Advice and involvement teams (see Sundstrom, De Meuse \& Futrell, 1990) were given the task of generating ideas for reducing costs, improving productivity, enhancing the quality of work life, and improving customer service. Membership was voluntary, with members serving at least two year terms. The managers of the area represented by the team submitted names of employees for inclusion in a team with human resources making the final selection of members. Each team was responsible for generating ideas and then gaining the acceptance of management to implement these ideas. Teams met formally at least once a week for an hour or more to work on solutions to problems they deemed important. In addition, 
informal meetings occurred between individual members and customers, coworkers, suppliers, and managers. Each team generated ideas that were submitted to a manager for approval.

\section{Participants}

The characteristics of the sample are summarized in table 1. Members of 59 teams were surveyed with a self-report questionnaire during the summer prior to the calendar year in which the effectiveness of the team was measured. Of 448 team members, 383 returned usable questionnaires for a return rate of $85 \%$. Member questionnaires were returned from 55 of the 59 teams, for a team return rate of $93 \%$. The number of respondents on each team ranged from three to eleven with five or more respondents reporting on fortyfive of the teams.

Table 1

Team Characteristics

\begin{tabular}{|l|r|r|}
\hline $\begin{array}{l}\text { Years as employee in } \\
\text { company }\end{array}$ & $\mathrm{M}=8.75$ & \\
\hline Months in team & $\mathrm{M}=14.99$ & \\
\hline Sex & Percent & \multicolumn{1}{|c|}{$\mathrm{N}$} \\
\hline Male & $62.20 \%$ & \\
\hline Female & $37.80 \%$ & \\
\hline Occupation & $15.50 \%$ & \\
\hline Managerial & $28.80 \%$ & 110 \\
\hline Professional & $16.50 \%$ & 63 \\
\hline Technical & $19.10 \%$ & 73 \\
\hline Secretarial & $16.20 \%$ & 62 \\
\hline Skilled craft or trade & $2.40 \%$ & 9 \\
\hline Other & & \\
\hline Frequency of team meetings & $21.70 \%$ & 83 \\
\hline once a week (4) & $46.60 \%$ & 178 \\
\hline every two weeks (3) & $11.80 \%$ & 45 \\
\hline every three weeks (2) & $17.80 \%$ & 68 \\
\hline Other (1) & & \\
\hline Attendance & & \\
\hline
\end{tabular}




\begin{tabular}{|c|r|r|}
\hline $100 \%$ & 0 & 0 \\
\hline $99-75 \%$ & $20.90 \%$ & 80 \\
\hline $74-50 \%$ & $67.30 \%$ & 257 \\
\hline $49-25 \%$ & $7.60 \%$ & 29 \\
\hline $24-0 \%$ & $1.60 \%$ & 6 \\
\hline other & $0.50 \%$ & 2 \\
\hline
\end{tabular}

\section{Variables Used in the Tests of the Hypotheses}

The three independent variables in the tests of the hypotheses were team size, functional heterogeneity, and teamwork quality. These independent variables were used to predict five dependent variables, each reflecting an aspect of team effectiveness.

1. Team size. The number of members in each group ranged from 5 - 15 . The mean group size was 8.47.

2. Functional heterogeneity. Respondents identified their job category (managerial, professional, technical, secretarial/clerical, skill craft or trade). Blau’s (1977) index of 
heterogeneity $1-\sum_{i}^{N}(p i)^{2}$ was used to calculate functional heterogeneity. Pi is the proportion of members in the $\mathrm{i}^{\text {th }}$ category, and $\mathrm{N}$ is the number of categories (i.e., 6). The index ranges from 0 (absolute homogeneity) to 1 (absolute heterogeneity).

3. Teamwork Quality. To measure the quality of teamwork, a self-report questionnaire was developed containing 49 items drawn from past research. Each of the items was answered on a four-point scale anchored with "Most of the time" (4), "Often" (3), "Seldom" (2), and "Never" (1). In forming the composite, items were reversed scored so that a higher value represented a more effective level of process. The items were intended to measure member perceptions of process dimensions commonly associated with the quality of teamwork. In tests of the hypotheses, an aggregate measure of teamwork quality was formed from the responses to the questionnaire items. The use of an aggregate measure has precedent in the team research and is consistent with LePine, et al's (2008, p. 294) contention that a broad measure is appropriate if the primary interest is general teamwork quality rather than specific dimensions.

4. Team effectiveness. The performance of the group was evaluated on five variables. The total number of ideas generated during the year and the number of these ideas that management approved (implemented ideas) were measured at the end of the first, second, and third calendar years following the administration of the questionnaire. The time lag between the collection of the performance data in the first year and the administration of the questionnaire was approximately fourteen months. Two other measures were the number of ideas generated per member and the number of ideas implemented per member. Each was computed by dividing the number of ideas generated and implemented by team size. Data on the number of ideas generated and implemented were missing for two of the 55 groups, reducing the number of teams to 53 in the analyses involving these variables. A fifth measure of performance was the mean of 
the managers' ratings of the team's effectiveness on nine items. Managers responded to each item using a four-point scale anchored with "Most of the time" (4), "Often" (3), "Seldom" (2), and "Never" (1). Managerial evaluations were available for 50 of the 55 groups.

\section{Variables Used in Exploratory Analyses}

A principal components analysis identified narrower teamwork quality themes that were used in follow-up, exploratory analyses. Based on a scree plot of eigenvalues, a varimax rotation with Kaiser normalization was used to force a five component solution. The items loading at .30 or higher on each component were averaged to form five subscores. The positive internal process subscale consisted of items indicating behaviors and attitudes conducive to good performance (e.g., "members are highly motivated to work for the success of this group," "members of my group come to meeting prepared," and "when the discussion strays, someone in the group will quickly get the members back on the main topic”). A second component was voice and consisted of items indicating involvement in the decisions of the team (e.g., "The opinions of all members are given equal consideration", and "every individual in the group feels that his or her ideas are welcome”). The perceived benefits scale reflected perceptions of members that group participation benefited them (e.g., "My participation in the focus group has improved my leadership skills," and "being a member of the focus group has helped me become more productive in my job”). The negative processes subscale consisted of behaviors and attitudes disruptive to team functioning (e.g., "a few of the members do most of the work", and “disagreement in my group deteriorates into bickering and conflict”). Finally, the management relationship subscale consisted of items indicating the extent to which the team worked well with management (e.g., “my group’s efforts are supported by our management” and “my group’s management responds promptly to the group’s proposals”). 


\section{Aggregation and Reliability Considerations}

Table 2 summarizes the evidence for the internal consistency, within group agreement, and reliability of the measures. A coefficient alpha was computed to assess the internal consistency of each scale. Interrater agreement was computed using $\mathrm{r}_{\mathrm{wg}}$ (James, Demaree \& Wolf, 1984) and the average deviation or AD (Smith-Crowe, Burke, Cohen and Doveh, 2014). The intraclass correlation was computed for a single item (ICC1) as well as the mean of the items in each scale (ICC avg). The findings provide support for the use of the independent and dependent variables used in the primary hypothesis testing. The evidence was not as strong for the five components but was considered sufficient for the purposes of exploratory analyses. 
Table 2

Reliability and Interrater Agreement of Measures

\begin{tabular}{|c|c|c|c|c|c|c|c|c|}
\hline \multirow[b]{2}{*}{ Variable } & \multirow[b]{2}{*}{$\begin{array}{c}\text { Number } \\
\text { Items }\end{array}$} & \multirow[b]{2}{*}{ Alpha } & \multicolumn{2}{|c|}{$\mathrm{AD}$} & \multicolumn{2}{|c|}{$\mathrm{r}_{\mathrm{wg}}$} & \multicolumn{2}{|c|}{ ICC } \\
\hline & & & Mean & Median & Mean & Median & $\operatorname{ICC}(1)$ & ICC(av) \\
\hline TeamQual. & 49 & .93 & .21 & .21 & .93 & .94 & .22 & .69 \\
\hline Manag. Relats. & 3 & .85 & .47 & .44 & .66 & .74 & .28 & .75 \\
\hline PosProc & 21 & .90 & .30 & .29 & .85 & .87 & .23 & .71 \\
\hline Benefits & 8 & .84 & .34 & .34 & .82 & .83 & .10 & .47 \\
\hline Voice & 8 & .74 & .29 & .29 & .87 & .90 & .07 & .37 \\
\hline Neg. Proc. & 10 & .79 & .22 & .18 & .89 & .92 & .14 & .56 \\
\hline Manag.Eval. & 9 & .88 & NA & NA & NA & NA & .44 & .88 \\
\hline Implem.Ideas & 3 & .88 & NA & NA & NA & NA & NA & NA \\
\hline Total Ideas & 3 & .84 & NA & NA & NA & NA & NA & NA \\
\hline
\end{tabular}

Note. TeamQual, Manag. Relats.,PosProc, Benefits, Voice, Neg. Proc., and Manag.eval. are the mean ratings on the teamwork quality, management relationships, positive process, perceived benefits, voice, negative processes, and management evaluation scales, respectively. Implem.Ideas and Total Ideas are the average of the number of ideas approved by management and the total ideas generated by the teams, respectively. NA indicates that the measure of interrater agreement or reliability was not applicable to the specific scale.

\section{Results}

Bivariate correlational and regression analyses were computed to test the hypotheses. The means, standard deviations, and bivariate correlations are reported in table 3. A separate hierarchical regression was conducted for each of the effectiveness measures (Cohen \& Cohen, 1975). An effectiveness measure was first regressed on group size, functional heterogeneity, and teamwork quality at the first step and then group size $\mathrm{X}$ teamwork quality and group size $\mathrm{X}$ functional heterogeneity products at the second step. A statistically significant contribution of a product term at the second step was taken as evidence of a moderator effect. The results of the regression analyses for each of the five effectiveness measures are reported in table 4. 
Table 3

Intercorrelations Among Variables

\begin{tabular}{|c|c|c|c|c|c|c|c|c|c|c|c|c|c|c|c|}
\hline Variable & Mean & SD & 1 & 2 & 3 & 4 & 5 & 6 & 7 & 8 & 9 & 10 & 11 & 12 & 13 \\
\hline Maneval (1) & 3.04 & .47 & 1 & $\begin{array}{l}.25 \\
(50)\end{array}$ & $\begin{array}{l}.14 \\
(50)\end{array}$ & $\begin{array}{l}.18 \\
(50)\end{array}$ & $\begin{array}{l}.04 \\
(50)\end{array}$ & $\begin{array}{l}.27 \\
(50)\end{array}$ & $\begin{array}{l}.04 \\
(50)\end{array}$ & $\begin{array}{l}.06 \\
(50)\end{array}$ & $\begin{array}{l}.47^{\star \star} \\
(50)\end{array}$ & $\begin{array}{l}-.14 \\
(50)\end{array}$ & $\begin{array}{l}.01 \\
(50)\end{array}$ & $\begin{array}{l}.03 \\
(50)\end{array}$ & $\begin{array}{l}.15 \\
(50)\end{array}$ \\
\hline $\begin{array}{l}\text { Implemented } \\
\text { Ideas (2) }\end{array}$ & 9.05 & 9.89 & & 1 & $\begin{array}{l}.92^{\star \star} \\
(53)\end{array}$ & $\begin{array}{l}.95^{\star \star} \\
(53)\end{array}$ & $\begin{array}{l}.85^{\star \star} \\
(53)\end{array}$ & $\begin{array}{l}.36^{*} \\
(53) \\
\end{array}$ & $\begin{array}{l}.37^{\star} \\
(53) \\
\end{array}$ & $\begin{array}{l}.28^{\star} \\
(53) \\
\end{array}$ & $\begin{array}{l}.26 \\
(53) \\
\end{array}$ & $\begin{array}{l}.17 \\
(53) \\
\end{array}$ & $\begin{array}{l}.02 \\
(53)\end{array}$ & $\begin{array}{l}.30^{*} \\
(53) \\
\end{array}$ & $\begin{array}{l}.31^{*} \\
(50)\end{array}$ \\
\hline Tot. Ideas (3) & 12.52 & 13.99 & & & 1 & $\begin{array}{l}.85^{\star \star} \\
(53) \\
\end{array}$ & $\begin{array}{l}.94^{* *} \\
(53)\end{array}$ & $\begin{array}{l}.30^{*} \\
(53)\end{array}$ & $\begin{array}{l}.33^{*} \\
(53) \\
\end{array}$ & $\begin{array}{l}.23 \\
(53)\end{array}$ & $\begin{array}{l}.19 \\
(53) \\
\end{array}$ & $\begin{array}{l}.12 \\
(53)\end{array}$ & $\begin{array}{l}.04 \\
(53)\end{array}$ & $\begin{array}{l}.26^{*} \\
(53)\end{array}$ & $\begin{array}{l}.29^{*} \\
(53)\end{array}$ \\
\hline $\begin{array}{l}\text { Implemented } \\
\text { per Mem. (4) }\end{array}$ & 1.04 & .97 & & & . & 1 & $\begin{array}{l}.90^{\star \star} \\
(53)\end{array}$ & $\begin{array}{l}.12 \\
(53) \\
\end{array}$ & $\begin{array}{l}.34^{*} \\
(53)\end{array}$ & $\begin{array}{l}.30^{*} \\
(53)\end{array}$ & $\begin{array}{l}.15 \\
(53) \\
\end{array}$ & $\begin{array}{l}.21 \\
(53)\end{array}$ & $\begin{array}{l}.05 \\
(53)\end{array}$ & $\begin{array}{l}.32^{\star} \\
(53)\end{array}$ & $\begin{array}{l}.32^{*} \\
(53)\end{array}$ \\
\hline $\begin{array}{l}\text { Total per } \\
\text { Mem. (5) }\end{array}$ & 1.46 & 1.34 & & & & & 1 & $\begin{array}{l}.04 \\
(53)\end{array}$ & $\begin{array}{l}.29^{*} \\
(53)\end{array}$ & $\begin{array}{l}.21 \\
(53)\end{array}$ & $\begin{array}{l}.06 \\
(53)\end{array}$ & $\begin{array}{l}.12 \\
(53)\end{array}$ & $\begin{array}{l}.07 \\
(53)\end{array}$ & $\begin{array}{l}.26 \\
(53)\end{array}$ & $\begin{array}{l}.30^{*} \\
(53)\end{array}$ \\
\hline Team Size(6) & 8.47 & 2.24 & & & & & & 1 & $\begin{array}{l}.21 \\
(55)\end{array}$ & $\begin{array}{l}-.03 \\
(55)\end{array}$ & $\begin{array}{l}.28^{*} \\
(55)\end{array}$ & $\begin{array}{l}-.19 \\
(55)\end{array}$ & $\begin{array}{l}-.09 \\
(55)\end{array}$ & $\begin{array}{l}-.05 \\
(55)\end{array}$ & $\begin{array}{l}-.02 \\
(55)\end{array}$ \\
\hline $\begin{array}{l}\text { Functional } \\
\text { Hetero. (7) }\end{array}$ & .50 & .22 & & & & & & & 1 & $\begin{array}{l}-.17 \\
(53)\end{array}$ & $\begin{array}{l}-.22 \\
(53)\end{array}$ & $\begin{array}{l}-.09 \\
(53)\end{array}$ & $\begin{array}{l}-.17 \\
(53)\end{array}$ & $\begin{array}{l}-.14 \\
(53)\end{array}$ & $\begin{array}{l}-.14 \\
(53)\end{array}$ \\
\hline $\begin{array}{l}\text { Teamwork } \\
\text { Quality (8) }\end{array}$ & 1.91 & .24 & & & & & & & & 1 & $\begin{array}{l}.53^{\star \star} \\
(55)\end{array}$ & $\begin{array}{l}.75^{\star \star} \\
(55)\end{array}$ & $\begin{array}{l}.75^{\star \star} \\
(55)\end{array}$ & $\begin{array}{l}.96^{\star \star} \\
(55)\end{array}$ & $\begin{array}{l}.82^{\star \star} \\
(53)\end{array}$ \\
\hline $\begin{array}{l}\text { Mngmt } \\
\text { Rels.(9) }\end{array}$ & 1.95 & .51 & & & & & & & & & 1 & $\begin{array}{l}.24 \\
(53)\end{array}$ & $\begin{array}{l}.28^{\star} \\
(53)\end{array}$ & $\begin{array}{l}.40^{*} \\
(53)\end{array}$ & $\begin{array}{l}.48^{\star \star} \\
(53)\end{array}$ \\
\hline Voice (10) & 1.59 & .19 & & & & & & & & & & 1 & $\begin{array}{l}.60^{* *} \\
(53)\end{array}$ & $\begin{array}{l}.71^{\star *} \\
(53)\end{array}$ & $\begin{array}{l}.48^{\star \star} \\
(53)\end{array}$ \\
\hline $\begin{array}{l}\text { Proc. Loss } \\
\text { (11) }\end{array}$ & 2.09 & .21 & & & & & & & & & & & 1 & $\begin{array}{l}.70^{\star \star} \\
(55)\end{array}$ & $\begin{array}{l}.40^{\star \star} \\
(55)\end{array}$ \\
\hline $\begin{array}{l}\text { Pos. Process } \\
\text { (12) }\end{array}$ & 1.91 & .31 & & & & & & & & & & & & 1 & $\begin{array}{l}.75^{\star \star} \\
(55)\end{array}$ \\
\hline $\begin{array}{l}\text { Perceived } \\
\text { Benefits (13) }\end{array}$ & 1.94 & .29 & & & & & & & & & & & & & 1 \\
\hline
\end{tabular}

${ }^{*} \mathrm{p}<.05 ;{ }^{* *} \mathrm{p}<.01$ 
Table 4

Regression of Team Effectiveness on Size, Heterogeneity, and Team Quality

\begin{tabular}{|c|c|c|c|c|c|c|c|c|c|c|}
\hline \multirow[b]{3}{*}{ Predictors } & \multicolumn{10}{|c|}{ Criterion } \\
\hline & \multicolumn{2}{|c|}{$\begin{array}{l}\text { Implemented } \\
\text { Ideas }\end{array}$} & \multicolumn{2}{|l|}{$\begin{array}{l}\text { Total } \\
\text { Ideas }\end{array}$} & \multicolumn{2}{|c|}{$\begin{array}{l}\text { Manager } \\
\text { Evaluation }\end{array}$} & \multicolumn{2}{|c|}{$\begin{array}{l}\text { Implemented } \\
\text { Ideas PerMem. }\end{array}$} & \multicolumn{2}{|c|}{$\begin{array}{l}\text { Total Ideas } \\
\text { Per Mem }\end{array}$} \\
\hline & $\beta$ & $\mathrm{R}^{2}$ & $\beta$ & $\mathrm{R}^{2}$ & $\beta$ & $\mathrm{R}^{2}$ & $\beta$ & $\mathrm{R}^{2}$ & $\beta$ & $\mathrm{R}^{2}$ \\
\hline Step 1 & & $.35 * *$ & & $.25 * *$ & & .08 & & $.24 * *$ & & $.16 *$ \\
\hline Size & $.29 *$ & & .25 & & .27 & & .05 & & -.02 & \\
\hline Hetero. & $.38 * *$ & & $.33 *$ & & .01 & & $.39 * *$ & & $.35 *$ & \\
\hline TeamQual & $.36^{* *}$ & & $.29 *$ & & .07 & & $.36 * *$ & & $.26^{*}$ & \\
\hline Step 2 & & $.48 * *$ & & $.40 * *$ & & .12 & & $.32 * *$ & & $.27 *$ \\
\hline $\begin{array}{l}\text { TeamQual } \\
\text { XSize }\end{array}$ & $3.20 * *$ & & $3.53 * *$ & & -1.01 & & $2.37 *$ & & $2.62 *$ & \\
\hline $\begin{array}{l}\text { Hetero } \\
\text { XSize }\end{array}$ & .92 & & 1.66 & & .80 & & .65 & & 1.11 & \\
\hline
\end{tabular}

$* \mathrm{p}<.05 ; * * \mathrm{p}<.01$

The first step yielded a significant $\mathrm{R}^{2}$ in the prediction of implemented ideas $(\mathrm{F}(3,49)=$ 8.66, $\mathrm{p}<.01)$, total ideas $(\mathrm{F}(3,49)=5.36, \mathrm{p}<.01)$, implemented ideas per member $(\mathrm{F}(3,49)=$ 5.29, $\mathrm{p}<.01)$, and total ideas per member $(\mathrm{F}(3,49)=3.03, \mathrm{p}<.05)$. Entry of the product terms at the second step yielded a statistically significant $\mathrm{R}^{2}$ in the prediction of implemented ideas ( $\mathrm{F}$ $(5,47)=8.62, \mathrm{p}<.01)$, total ideas $(\mathrm{F}(5,47)=6.25, \mathrm{p}<.01)$, implemented ideas per member $(\mathrm{F}$ $(5,47)=4.33, \mathrm{p}<.01)$, and the total ideas per member $(\mathrm{F}(3,49)=3.52, \mathrm{p}<.01)$. The $\mathrm{R}^{2}$ at the first and second steps was statistically nonsignificant in the prediction of managerial evaluations.

\section{Hypothesis 1: Teamwork Quality as a Predictor}

In support of hypothesis 1 , the bivariate correlations for teamwork quality were statistically significant for the number of implemented ideas $(r=.28, p<.05)$ and the number of implemented ideas per member $(r=.30, \mathrm{p}<.05)$ but were statistically nonsignificant for total ideas $(r=.23$, ns) and total ideas per member $(r=.21$, ns). The regression analyses showed that 
teamwork quality was positively related to the number of implemented ideas $(ß=.36, t=3.05$, $p$ $<.01)$, total ideas $(ß=.29, \mathrm{t}=2.33, \mathrm{p}<.05)$, implemented ideas per member $(ß=.36, \mathrm{t}=2.89, \mathrm{p}<$ $.01)$, and total ideas per member $(ß=.26, \mathrm{t}=2.01, \mathrm{p}<.05)$. Teamwork quality was unrelated to managerial evaluations.

\section{Hypothesis 2: Functional Heterogeneity as a Predictor}

Consistent with hypothesis 2, higher functional heterogeneity was positively related to the number of total ideas $(r=.33, \mathrm{p}<.05)$, the number of implemented ideas $(r=.38, \mathrm{p}<.01)$, the number of implemented ideas per member $(r=.34, \mathrm{p}<.05)$, and the number of total ideas per member $(\mathrm{r}=.29, \mathrm{p}<.05)$. Also consistent with hypothesis 2 , the standardized partial regression coefficients indicated that the more heterogeneous groups generated more implemented ideas ( $ß$ $=.38, \mathrm{t}=3.15, \mathrm{p}<.01)$, more total ideas $(ß=.33, \mathrm{t}=2.53, \mathrm{p}<.05)$, more implemented ideas per member $(ß=.39, \mathrm{t}=3.02, \mathrm{p}<.01)$, and more total ideas per member $(ß=.35, \mathrm{t}=2.53, \mathrm{p}<.05)$. The correlation and the standardized partial regression coefficients were statistically nonsignificant for managerial evaluations.

\section{Hypothesis 3: Team Size as a Predictor}

Consistent with hypothesis 3, larger team size was associated with more implemented ideas $(r=.36, p<.01)$ and more total ideas $(r=.30, p<.05)$. The regression of the number of implemented ideas on the predictors indicated that larger groups had more implemented ideas ( $=.29, \mathrm{t}=2.48, \mathrm{p}<.05)$. The standardized partial regression coefficients obtained for group size were statistically nonsignificant in the prediction of implemented ideas per member $(ß=-.05, \mathrm{t}$ $=.418, \mathrm{~ns})$ and total ideas per member $(\Omega=-.02, \mathrm{t}=.14$, ns). Marginally significant effects for managerial evaluations indicated a tendency for larger groups to receive more positive evaluations $(ß=.27, \mathrm{t}=1.85, \mathrm{p}<.08)$ and more total ideas $(ß=.25, \mathrm{t}=1.94, \mathrm{p}<.06)$. 


\section{Hypothesis 4: Team Size as a Moderator}

Support was found for hypothesis 4 on four of the five criterion measures. Consistent with the hypothesis, the standardized partial regression coefficient of the product of size and teamwork quality was statistically significant for the number of implemented ideas $(ß=3.20$, $\mathrm{t}=3.13, \mathrm{p}<.01)$, total ideas $(ß=3.53, \mathrm{t}=3.22, \mathrm{p}<.01)$, implemented ideas per member $(ß=2.37$, $\mathrm{t}=2.03, \mathrm{p}<.05)$ and total ideas per member $(ß=3.17, \mathrm{t}=2.62, \mathrm{p}<.05)$. The positive regression coefficient indicated that increasing the size of the team amplified the beneficial effects of teamwork quality. The standardized regression coefficient was statistically nonsignificant for managerial evaluations.

To further interpret the two-way interaction found for team size and team process, the samples were split at the median on team size $(\mathrm{n}<9=$ small; $\mathrm{n}>8=$ large). The correlations between the process measures and the effectiveness measures within the large and small teams are reported in table 5. The correlations of teamwork quality with implemented ideas, total ideas, ideas implemented per member, and total ideas per member were positive and larger for the large teams than for the small teams. Each of the effectiveness measures was plotted against teamwork quality for large and small teams. Similar results were found for all the measures except for managerial evaluations, but only the plot for the number of implemented ideas is presented in figure 1. The comparisons reported in figures 1 and table 5 are intended to help interpret the moderating effect found for the continuous measure of size and are not primary tests of the hypotheses. 
Table 5

The Correlations Between Teamwork Quality and Team Effectiveness

in the Large and Small Teams

\begin{tabular}{|l|l|l|l|}
\hline & \multicolumn{2}{|l|}{ Team Size } & \\
\hline Effectiveness Measure & Large & Small & $\mathrm{Z}$ \\
\hline Implemented Ideas & $.58^{*}$ & -.03 & $2.35^{*}$ \\
\hline Total Ideas & $.48^{*}$ & -.08 & $2.04^{*}$ \\
\hline Managerial Evaluation & .01 & .13 & $\mathrm{~ns}$ \\
\hline Implemented Per Member & $.60^{* *}$ & .02 & $2.28^{*}$ \\
\hline Total Per Member & $.51^{* *}$ & -.08 & $2.18^{*}$ \\
\hline $\mathrm{N}$ & 23 & 30 & \\
${ }^{*} \mathrm{p}<.05$ & \multicolumn{3}{l}{} \\
\end{tabular}

Figure 1. Scatterplot for Regression of Number of Implemented

Ideas on Teamwork Quality in Small and Large teams.

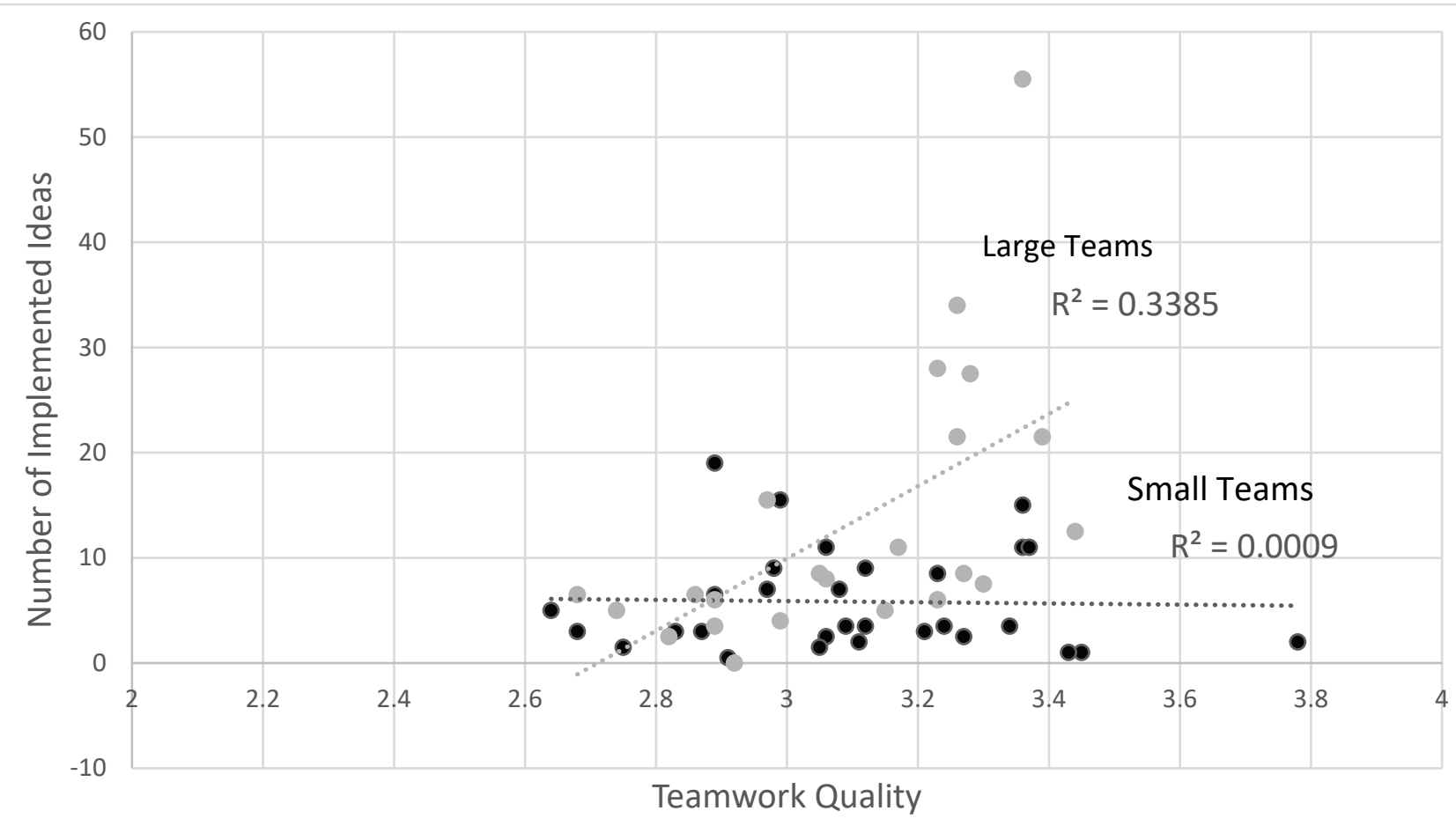




\section{Exploratory Analyses}

To further illuminate the results of the hypotheses tests, exploratory analyses were conducted using the teamwork quality subscores. A separate multiple regression analysis was conducted for each of the five subscores following the same regression procedures used in the analysis of the aggregate teamwork quality measure. The findings for the teamwork quality measure were for the most part replicated with the positive process, perceived benefits, and managerial relationships measures. Although the aggregate teamwork quality measure was unrelated to managerial evaluations, the management relations subcomponent of this aggregate was positively related to managerial evaluations after controlling for size and functional heterogeneity $(ß=.47, \mathrm{t}=3.35, \mathrm{p}<.01)$. The only statistically significant relation found for voice was for the number of implemented ideas. After controlling for size and heterogeneity, reports of voice was associated with more implemented ideas $(ß=.26, \mathrm{t}=2.12, \mathrm{p}<.05)$. The negative process subcomponent was unrelated to all five of the effectiveness measures in the bivariate and multiple regression analyses.

\section{Discussion}

The findings of the present study confirmed the importance as predictors of team effectiveness of quality teamwork and two compositional factors - size and functional heterogeneity. Specifically, larger teams whose members were diverse in their functional affiliations and who reported high quality teamwork were more productive over a three-year period than smaller, functionally homogeneous teams with lower quality teamwork. The findings show that team size moderated the relation of high quality teamwork to team effectiveness with a much stronger positive relation occurring in larger teams than in smaller teams. Contrary to studies showing a loss of efficiency in productivity with larger size or heterogeneity (Brandt \& 
Schubert, 2013; Cook, Grange \& Eyre-Walker, 2015; Gooding \& Wagner, 1985; Valacich, Wheeler, Mennecke \& Wachter,1995), team size and heterogeneity were unrelated to the number of total ideas generated per member and the number of implemented ideas per member.

It should be noted that these effects were found for the objective measures of effectiveness (i.e., total number of ideas generated, number of ideas implemented, total number generated and implemented per member) but not for the more subjective managerial evaluations of team effectiveness. The only statistically significant correlations found for managerial evaluations were for the managerial relationships subscale. The more team members perceived a good relationship with their management, the more positive the manager's evaluation of their effectiveness. A definitive explanation for these findings is not possible in the context of this study. Nonetheless, it is plausible that the large, heterogeneous teams had an advantage because of a larger and more diverse pool of ideas, more varied approaches to the problems, and connections to others outside the team. That only the managerial relationships subscale was related to managerial evaluations of the teams suggests that the manager's judgment of effectiveness was shaped more by how well they interacted with the team than the actual productivity of the team. It is also possible that managers based their evaluations on team contributions to outcomes other than the generation of ideas such as building morale (Sutton \& Hargadon, 1996).

Of particular interest is the moderating effect of team size on the correlation between teamwork quality and team effectiveness. Contrary to hypothesis 5, team size did not moderate the relation of functional heterogeneity and team effectiveness, but consistent with hypothesis 4 , a strong interaction effect was found between team size and teamwork quality. The evidence of a moderating effect suggests that a team with high quality teamwork has the potential to perform 
more effectively than one with lower teamwork quality, but that the full potential of the team is not realized until there is a sufficient number of members to generate unique ideas and generate synergy. It is equally valid, given the correlational nature of the study, to conclude that forming a large team improves performance only when teamwork quality is also high. Efforts to manage internal processes in a small team could divert resources from the task and cancel the benefits of high quality teamwork. As the team grows in size, the greater pool of ideas and connections with outside sources of ideas, coupled with high quality teamwork, unleashes the energy and creativity of the team. These findings also raise the possibility that some of the evidence that internal group process is unrelated to outcomes reflects the use of small teams (e.g., Gladstein, 1984).

\section{Limitations and Boundary Conditions}

There are several caveats and limitations worth mentioning. An aggregate measure of teamwork quality was used in testing the hypotheses rather than attempting to single out specific dimensions of teamwork. The self-reports of teamwork quality in this study no doubt reflect a complex mix of factors including actual behaviors (Kauffeld \& Lehmann-Willenbrock, 2012), the collective expectancies of members (Gully, et al, 2002)., the general affective tone within the team (Barsade \& Gibson, 2012; Collins Lawrence, Troth, \& Jordan, 2013), and social cohesion (Gully, Devine \& Whitney, 2012; Hülsheger, et al, 2009). An aggregate measure is a plausible and perhaps preferred approach to the extent that teams are viewed as open, complex systems containing interconnected sentiments, actions, and interactions (Arrow, McGrath \& Berdahl, 2000; Homans, 1950). Nonetheless, research is needed to identify the relative impact of the teamwork dimensions that were subsumed in the aggregate measure. 
Contrary to some previous findings, size served as an advantage in the teams sampled in this study, but this is not to suggest that effectiveness increases ad infinitum as size increases. Eventually any team reaches a point of too many members, and the point where this occurs is likely to depend on the task. Another potentially important boundary to the generalizability of these findings is that the teams were relative mature and had worked together an average of $1 \frac{1 / 2}{2}$ years. It is possible that in ad hoc teams composed of strangers or in less mature teams, the benefits of heterogeneity and size are attenuated (Harrison, Price \& Gavin, 2002) while negative consequences are magnified (e.g., Kauffeld \& Lehmann-Willenbrock, 2012). Finally, as is typically the case in correlational studies, caution must be observed in inferring causal relations. Careful experimentation in controlled settings is still needed to complement the field research. Nonetheless, for teams operating in an organizational context, the delineation among input, throughput, and outcome are inevitably blurred. For instance, both size and functional heterogeneity could be an outcome as well as an input. Team success and high quality teamwork may lead managers to assign more members to a team whereas failure and low quality teamwork could lead to fewer members. Similarly, teamwork quality could constitute an input to the extent members bring prior working relationships to the team, a throughput to the extent that it emerges from compositional and other input variables, and an outcome to the extent that success encourages and failure inhibits teamwork.

\section{Conclusions}

The findings have implications for how future research is conducted on teams in field settings. Perhaps the most important of these is that size matters for teams tasked with generating ideas. Field researchers should treat it as an important predictor of effectiveness rather than relegating it to the status of a mere control variable. The results also support previous observations that subjective judgments of team effectiveness are not equivalent to objective 
measures and that researchers should use multiple criteria of team success (e.g. van Dijk et al, 2012). Finally, rather than relying on concurrent, cross-sectional designs, research is needed that uses predictive models to assess how well team characteristics forecast effectiveness (see Staw, 1975). Notwithstanding the limitations, the implications for forming and managing teams are clear. To improve the effectiveness of teams whose primary mission is to generate creative and innovative ideas, management should form relatively large teams (i.e., 10 - 15) that represent diverse functional areas and then implement training and monitoring to ensure high quality teamwork. 


\section{References}

Allen, N. J., \& Hecht, T. D. (2004). The 'romance of teams': Toward an understanding of its psychological underpinnings and implications. Journal of Occupational and Organizational Psychology, 77, 439-461. doi:10.1348/0963179042596469

Alexander, L., \& Van Knippenberg, D. (2014). Teams in pursuit of radical innovation: A goal orientation perspective. The Academy of Management Review, 39, 423-438. doi:10.5465/amr.2012.0044

Ancona, D. G., \& Caldwell, D. F. (1992). Bridging the boundary: External activity and performance in organizational teams. Administrative Science Quarterly, 37, 634-665. doi:10.2307/2393475

Arrow, H., McGrath, J. E., \& Berdahl, J. L. (2000). Small groups as complex systems: formation, coordination, development, and adaptation. Thousand Oaks, Ca.: Sage.

Bales, R. F., Strodtbeck, F. L., Mills, T. M., \& Roseborough, M. E. (1951). Channels of communication in small groups. American Sociological Review, 16, 461-468. doi:10.2307/2088276

Barsade, S. G., \& Gibson, D. E. (2012). Group affect: Its influence on individual and group outcomes. Current Directions in Psychological Science, 21, 119-123. doi:10.1177/0963721412438352

Bell, S. T., Villado, A. J., Lukasik, M. A., Belau, L., \& Briggs, A. L. (2011). Getting specific about demographic diversity variable and team performance relationships: A metaanalysis. Journal of Management, 37, 709-743. doi:10.1177/0149206310365001

Brandt, T. \& Schubert T. (2013). Is the university model an organizational necessity? Scale and 
agglomeration effects in science. Scientometrics, 94, 541-565 DOI 10.1007/s11192-012$0834-2$

Baruah, J., \& Paulus, P. B. (2011). Category assignment and relatedness in the group ideation process. Journal of Experimental Social Psychology, 47, 1070-1077. doi:10.1016/j.jesp.2011.04.007

Bray, R. M., Kerr, N. L., \& Atkin, R. S. (1978). Effects of group size, problem difficulty, and sex on group performance and member reactions. Journal of Personality and Social Psychology, 36, 1224-1240. doi:10.1037/0022-3514.36.11.1224

Brown, V. R., \& Paulus, P. B. (2002). Making group brainstorming more effective: Recommendations from an associative memory perspective. Current Directions in Psychological Science, 11, 208-212. doi:10.1111/1467-8721.00202

Cohen, J., \& Cohen, P. (1975). Applied multiple regression/correlational analysis for the behavioral science. New York: John Wiley \& Sons.

Cohen, M. A., Rogelberg, S. G., Allen, J. A., \& Luong, A. (2011). Meeting design characteristics and attendee perceptions of staff/team meeting quality. Group Dynamics: Theory, Research, and Practice, 15, 90-104. doi:10.1037/a0021549

Collins, A. L., Lawrence, S. A., Troth, A. C., \& Jordan, P. J. (2013). Group affective tone: A review and future research directions. Journal of Organizational Behavior, 34(Suppl 1), S43-S62. doi:10.1002/job.1887

Cook, I., Grange, S. \& Eyre-Walker, A. (2015). Research groups: How big should they be? PeerJ 3:e989 DOI 10.7717/peerj.989 
De Dreu, C. W. (2002). Team innovation and team effectiveness: The importance of minority dissent and reflexivity. European Journal of Work and Organizational Psychology, 11, 285-298. doi:10.1080/13594320244000175

Dennis, A. R., \& Williams, M. L. (2005). A meta-analysis of group size effects in electronic brainstorming: More heads are better than one. International Journal of e-Collaboration, 1, 24-42.

Dugosh, K. L., \& Paulus, P. B. (2005). Cognitive and social comparison processes in brainstorming. Journal of Experimental Social Psychology, 41, 313-320. doi:10.1016/j.jesp.2004.05.009

Geen, R. G. (1989). Alternative conceptions of social facilitation. In P. B. Paulus, P. B. Paulus (Eds.), Psychology of group influence, 2nd ed (pp. 15-51). Hillsdale, NJ, US: Lawrence Erlbaum Associates, Inc.

Gladstein, D. L. (1984). Groups in context: A model of task group effectiveness. Administrative Science Quarterly, 29, 499-517.

Gooding, R. Z, \& Wagner, J. A. III (1985). A meta-analytic review of the relationship between size and performance: The productivity and efficiency of organizations and their subunits. Administrative Science Quarterly, 30, 462-481.

Gully, S. M., Devine, D. J., \& Whitney, D. J. (2012). A meta-analysis of cohesion and performance: Effects of level of analysis and task interdependence. Small Group Research, 43, 702-725. doi:10.1177/104649641246806

Gully, S. M., Incalceterra, K. A., Joshi, A., Beaubien, J. M. (2002). A meta-analysis of teamefficacy, potency, and performance: Interdependence and level of analysis as moderators of observed relationships. Journal of Applied Psychology, 87, 810 - 832. 
Hare, A. P. (1981). Group size. American Behavioral Scientist, 24, 695-708.

Harrison, D. A., Price, K. H., Gavin, J. H., \& Florey, A. T. (2002). Time, teams, and task performance: Changing effects of surface- and deep-level diversity on group functioning. Academy of Management Journal, 45, 1029-1045. doi:10.2307/3069328

Heninger, W. G., Dennis, A. R., \& Hilmer, K. M. (2006). Individual cognition and dual-task interference in group support systems. Information Systems Research, 17, 415-424. doi:10.1287/isre.1060.0102

Homans, G. (1950). The Human Group. New York: Routledge.

Hülsheger, U. R., Anderson, N., \& Salgado, J. F. (2009). Team-level predictors of innovation at work: A comprehensive meta-analysis spanning three decades of research. Journal of Applied Psychology, 94, 1128-1145. doi:10.1037/a0015978

James, L. R., Demaree, R. G., \& Wolf, G. (1984). Estimating within-group interrater reliability with and without response bias. Journal of Applied Psychology, 69, 85-98.

Kauffeld, S. \& Lehmann-Willenbrock, N. (2012). Meetings matter: Effects of team meetings on team and organization success. Small Group Research, 43, 130-158. http://dx.doi.org.ezproxy.net.ucf.edu/10.1177/1046496411429599

Kolfschoten, G. L., \& Brazier, F. T. (2013). Cognitive load in collaboration: Convergence. Group Decision and Negotiation, 22, 975-996. doi:10.1007/s10726-012-9322-6

Kong-Hee, K. (2014). Board heterogeneity: Double-edged sword? Focusing on the moderating effects of risk on heterogeneity - performance linkage. Academy of Strategic Management Journal, 13, 129-145

Latané, B. (1981). The psychology of social impact. American Psychologist, 36, 343-356. doi:10.1037/0003-066X.36.4.343 
LePine, J. A., Piccolo, R. F., Jackson, C. L., Mathieu, J. E., \& Saul, J. R. (2008). A meta-analysis of teamwork processes: Tests of a multidimensional model and relationships with team effectiveness criteria. Personnel Psychology, 61, 273-307. doi:10.1111/j.17446570.2008.00114.x

Liden, R. C., Wayne, S. J., Jaworski, R. A., \& Bennett, N. (2004). Social loafing: A field investigation. Journal of Management, 30, 285-304. doi:10.1016/j.jm.2003.02.002

Locke, E. A., Tirnauer, D., Roberson, Q., Goldman, B., Latham, M. E., \& Weldon, E. (2001). The importance of the individual in an age of groupism. In M. Turner (Ed.), Groups at work: Theory and research (pp. 501-528). Mahwah, NJ: Erlbaum.

Moreland, R. L., Levine, J. M., \& Wingert, M. L. (1996). Creating the ideal group: Composition effects at work. In E. H. Witte, J. H. Davis, E. H. Witte, J. H. Davis (Eds.), Understanding group behavior, Vol. 2: Small group processes and interpersonal relations (pp. 11-35). Hillsdale, NJ, US: Lawrence Erlbaum Associates, Inc.

Mueller, J. S. (2012). Why individuals in larger teams perform worse. Organizational Behavior and Human Decision Processes. 117, 111-124.

Mullen, B., Johnson, C., \& Salas, E. (1991). Productivity loss in brainstorming groups: A metaanalytic integration. Basic and Applied Social Psychology, 12, 3-23. doi:10.1207/s15324834basp120

Naquin, C. E. \& Tynan, R. O. (2003). The team halo effect: Why teams are not blamed for their failures. Journal of Applied Psychology, 88, 332-340.

Perry-Smith, J. E., \& Shalley, C. E. (2014). A social composition view of team creativity: The role of member nationality-heterogeneous ties outside of the team. Organization Science, 25, 1434-1452. doi:10.1287/orsc.2014.0912 
Randel, A. E., Jaussi, K. S., \& Wu, A. (2011). When does being creative lead to being rated as creative? The moderating role of perceived probability of successfully bringing ideas to a supervisor's attention. Creativity Research Journal, 23, 1-8.

doi:10.1080/10400419.2011.545699

Rousseau, V., \& Aubé, C. (2014). The reward-performance relationship in work teams: The role of leader behaviors and team commitment. Group Processes \& Intergroup Relations, 17, 645-662. doi:10.1177/1368430214529465

Schmidt, S. M., \& Kochan, T. A. (1972). Conflict: Toward conceptual clarity. Administrative Science Quarterly, 17, 359-370. doi:10.2307/2392149

Shaw, J. D., Duffy, M. K., \& Stark, E. M. (2001). Team reward attitude: Construct development and initial validation. Journal of Organizational Behavior, 22, 903-917. doi:10.1002/job.121

Shea, G. P., \& Guzzo, R. A. (1987). Groups as human resources. In G. Ferris \& K. Rowland (ed.). Groups as human resources. Research in personnel and human resources management, 5, Greenwich, Conn: JAI Press, 323-356.

Sheppard, J. A. (1993). Productivity loss in performance groups: A motivation analysis. Psychological Bulletin, 113, 67-81.

Simons, T., Pelled, L. H., \& Smith, K. A. (1999). Making use of difference: Diversity, debate, and decision comprehensiveness in top management teams. Academy of Management Journal, 42, 662-673. doi:10.2307/256987

Škerlavaj, M., Černe, M., \& Dysvik, A. (2014). I get by with a little help from my supervisor: Creative-idea generation, idea implementation, and perceived supervisor support. The Leadership Quarterly, 25, 987-1000. doi:10.1016/j.leaqua.2014.05.003 
Smith-Crowe, K., Burke, M. J., Cohen, A., \& Doveh, E. (2014). Statistical significance criteria for the $\mathrm{r}_{\mathrm{wg}}$ and average deviation interrater agreement indices. Journal of Applied Psychology, 99, 239-261. doi:10.1037/a0034556

Somech, A. (2006). The Effects of Leadership Style and Team Process on Performance and Innovation in functionally heterogeneous teams. Journal of Management, 32, 132-157. doi:10.1177/0149206305277799

Somech, A., \& Drach-Zahavy, A. (2013). Translating team creativity to innovation implementation: The role of team composition and climate for innovation. Journal of Management, 39, 684-708. doi:10.1177/0149206310394187

Somech, A., \& Khalaili, A. (2014). Team boundary activity: Its mediating role in the relationship between structural conditions and team innovation. Group \& Organization Management, 39, 274-299. doi:10.1177/1059601114525437

Staats, B. R., Milkman, K. L., \& Fox, C. R. (2012). The team scaling fallacy: Underestimating the declining efficiency of larger teams. Organizational Behavior and Human Decision Processes, 118, 132-142. doi:10.1016/j.obhdp.2012.03.002

Stajkovic, A. D., Lee, D., \& Nyberg, A. J. (2009). Collective efficacy, group potency, and group performance: Meta-analyses of their relationships, and test of a mediation model. Journal of Applied Psychology, 94, 814-828. doi:10.1037/a0015659

Staw, B. M. (1975). Attribution of the "causes" of performance: A general alternative interpretation of cross-sectional research on organizations. Organizational Behavior and Human Performance, 13, 414-432.

Steiner, I. D. (1972). Group process and productivity. New York: Academic Press. 
Sundstrom, E., De Meuse, K. P., \& Futrell, D. (1990). Work teams: Applications and effectiveness. American Psychologist, 45, 120-133.

Sutton, R. I., \& Hargadon, A. (1996). Brainstorming groups in context: Effectiveness in a product design firm. Administrative Science Quarterly, 41, 685-718. doi:10.2307/2393872

Thatcher, S. B., \& Patel, P. C. (2011). Demographic faultlines: A meta-analysis of the literature. Journal of Applied Psychology, 96, 1119-1139. doi:10.1037/a0024167

Thomas, E. J., \& Fink, C. F. (1963). Effects of group size. Psychological Bulletin, 60, 371-384. doi:10.1037/h0047169

Umseem, J. (June 1, 2006). How to build a great team. Fortune (retrieved from http://archive.fortune.com/2006/05/31/magazines/fortune/intro_greatteams_fortune_0612 06/index.htm)

Valacich, J. S., Wheeler, B. C., Mennecke, B. E., \& Wachter, R. (1995). The effects of numerical and logical group size on computer-mediated idea generation. Organizational Behavior and Human Decision Processes, 62, 318-329. doi:10.1006/obhd.1995.1053

van Dijk, H., van Engen, M. L., \& van Knippenberg, D. (2012). Defying conventional wisdom: A meta-analytical examination of the differences between demographic and job-related diversity relationships with performance. Organizational Behavior and Human Decision Processes, 119, 38-53. doi:10.1016/j.obhdp.2012.06.003

Webber, S. S., \& Donahue, L. M. (2001). Impact of highly and less job-related diversity on work group cohesion and performance: A meta-analysis. Journal of Management, 27, 141-162. doi:10.1016/S0149-2063(00)00093-3 
West, M. A.\& Anderson, N. R. (1996). Innovation in top management teams. Journal of Applied Psychology, 81, 680-693. 